JOANNA BANASIUK

Uniwersytet w Białymstoku

\title{
CZY EUROPEJSKA KONWENCJA PRAW CZŁOWIEKA JAKO „ŻYWY INSTRUMENT” CHRONI LEPIEJ LUDZKIE ŻYCIE?
}

\section{WSTĘP}

System Rady Europy, w szczególności Europejska Konwencja o Ochronie Praw Człowieka i Podstawowych Wolności (EKPCz) oraz Europejski Trybunał Praw Człowieka (ETPCz), odgrywa istotną rolę w przedmiocie kształtowania treści praw podstawowych i standardów ich ochrony ${ }^{1}$. Jednym $\mathrm{z}$ aspektów oddziaływania strasburskiego systemu na ochronę praw człowieka jest traktowanie Konwencji jako „żywego instrumentu"2. Umożliwia to dynamiczną interpretację przepisów konwencyjnych, z jednej strony dostosowaną do zmieniających się warunków społecznych oraz uwzględniającą bogactwo rozstrzyganych stanów faktycznych ${ }^{3}$, z drugiej jednak strony odchodzącą coraz wyraźniej od tekstu samej Konwencji. W konsekwencji podlega ona nieustannej ewolucji w zakresie kształtowania treści gwarancji kon-

1 Por. A. Wróbel, [w:] Karta Praw Podstawowych Unii Europejskiej. Komentarz, red. A. WróBel, Warszawa 2013, s. 7.

2 Por. C. GRewe, Beitritt der EU zur EMRK und ZP 14: Wirksame Durchsetzung einer gesamteuropäischen Grundrechteverfassung?, «Europarecht» 3/2012, s. 293.

3 Por. A. Peters, Einführung in die Europäische Menschenrechtskonvention. Mit rechtsvergleichenden Bezügen zum deutschen Grundgesetz, Monachium 2003, s. 1819. 
wencyjnych ${ }^{4}$. Dostrzegając kreatywny charakter działalności orzeczniczej, Europejski Trybunał Praw Człowieka w wyroku z dnia 18 grudnia 1986 r. w sprawie Johnston $i$ in. przeciwko Irlandii ${ }^{5}$ podkreślił jednocześnie, że ewolucyjna interpretacja postanowień Konwencji nie może być podstawą do wprowadzania do Konwencji praw, które nie były w niej zawarte od początku. Obserwowany ostatnio rozwój orzecznictwa ETPCz każe jednak zadać pytanie o to, jak bardzo Trybunał czuje się wciąż związany tym stanowiskiem. Analiza dorobku trybunału strasburskiego uwidacznia daleko idącą specyfikę sposobu wykładni norm konwencyjnych, poważnie rozszerzającą ich treść ${ }^{6}$ i to w sposób budzący często istotne kontrowersje. Niekiedy można odnieść wrażenie, że Trybunał z biegiem czasu w coraz mniejszym stopniu czuje się związany tekstem samej Konwencji. Stanowisko to podzielił Sędzia ETPCz E. Myjer w zdaniu odrębnym do wyroku z dnia 8 grudnia 2009 r. w sprawie Muñoz Díaz przeciwko Hiszpanii ${ }^{7}$, uznając, że kreacyjna działalność Trybunału w przedmiocie treści norm konwencyjnych jest nieuprawniona. Europejski Trybunał Praw Człowieka, przywłaszczając sobie kompetencję tworzenia praw nieprzewidzianych przez autorów podpisanej w połowie XX w. umowy międzynarodowej, wystawia na szwank swą wiarygodność wśród państw-stron Konwencji jako organ sądowniczy.

Dynamiczny charakter wykładni konwencyjnych norm prawnych jest zagadnieniem szczególnie istotnym w kontekście prawa do życia, będącego fundamentem Konwencji per $s e^{8}$. Zgodnie $\mathrm{z}$ art. $2 \mathrm{EKPCz}$ prawo każdego człowieka do życia jest chronione przez ustawę. Prima facie wydaje się, że w procesie wykładni norm konwencyjnych powinno

4 L. Garlicki, [w:] Konwencja o Ochronie Praw Człowieka i Podstawowych Wolności. Komentarz do artykułów 1-18. I, red. L. GARLicki, Warszawa 2010, s. 482.

5 Skarga nr 9697/82.

6 Por. P.A. Świtalski, Miejsce Rady Europy w europejskiej architekturze instytucjonalnej, [w:] 60 lat Rady Europy. Tworzenie i stosowanie standardów prawnych, red. H. MACHIŃSKA, Warszawa 2009, s. 28-29.

7 Skarga nr 49151/07.

8 Por. J. Borrego Borrego, Problems of Frivolity in the European Court of Human Rights, s. 174. 
się przyznawać ochronie życia ludzkiego nadrzędny charakter. Jak wskazano w wyroku ETPCz z 27 września 1995 r. w sprawie McCann $i$ in. przeciwko Zjednoczonemu Królestwu ${ }^{9}$, wszystkie odstępstwa od tej zasady powinny charakteryzować się następującymi cechami: powinny posiadać wyjątkowy charakter, wyraźną podstawę w treści norm prawnych i podlegać wykładni zwężającej; stanowisko to jest afirmowane przez doktrynę ${ }^{10}$. Tymczasem analiza późniejszego orzecznictwa Europejskiego Trybunału Praw Człowieka pokazuje dość wyraźnie, że konsekwentnie pomija ono te wytyczne.

Niniejszy artykuł ilustruje sposób, w jaki zachodzą te kontrowersyjne procesy, na przykładzie wyroku z 30 października 2012 r. w sprawie P. i S. przeciwko Polsce ${ }^{11}$, który, jak już dostrzegli to niektórzy komentatorzy ${ }^{12}$, zdaje się zmierzać ku konstruowaniu prawa do aborcji wywodzonego z art. 8 Konwencji i rozpatrywanego w całkowitym oderwaniu od gwarancji ochrony życia ludzkiego zawartych w jej art. 2.

W związku z charakterem Konwencji, analiza przedmiotowego zagadnienia wymaga właściwego ustalenia polskiego kontekstu normatywnego w przedmiocie dopuszczalności zabiegu przerwania ciąży. Na tym tle zostanie następnie przybliżony stan faktyczny sprawy oraz argumentacja Europejskiego Trybunału Praw Człowieka. Pozwoli to w dalszej kolejności na dokonanie oceny stanowiska ETPCz w kontekście obowiązujących polskich rozwiązań normatywnych.

\footnotetext{
9 Skarga nr 18984/91.

10 L. Garlicki, [w:] Konwencja o Ochronie Praw Człowieka i Podstawowych Wolności..., I, s. 65.

11 Skarga nr 57375/08.

12 G. PuppInck, Procedural Obligations under the European Convention on Human Rights: an Instrument to Stretch Access to Abortion, «Zeszyty Prawnicze»13.1, s. 215 i n.; L. Volontè, pytanie nr 633 do Komitetu Ministrów | Doc. 13.181 | 23 kwietnia 2013. Czy Europejska Konwencja Praw Człowieka gwarantuje prawo do aborcji? http://assembly.coe.int/ASP/Doc/XrefDocDetails_E.asp?FileID=19649, dostęp 24 czerwca 2013 r.
} 


\section{Polski KonteKst NORMATYwny}

W polskim prawie przesłanki ustawowo dopuszczalnego przerwania ciąży unormowane są w ustawie z dnia 7 stycznia 1993 r. o planowaniu rodziny, ochronie płodu ludzkiego i warunkach dopuszczalności przerywania ciąży ${ }^{13}$. Wskazane przypadki, w których lekarz może przeprowadzić zabieg przerwania ciąży, traktować należy jako wyjątek od konstytucyjnej zasady ochrony życia, którego konstytucyjność wszakże budzi wątpliwości ${ }^{14}$. Zgodnie $\mathrm{z}$ art. 4a u.p.r. przerwanie ciąży może być dokonane wyłącznie przez lekarza, w przypadkach, kiedy ciąża stanowi zagrożenie dla życia lub zdrowia kobiety ciężarnej, kiedy badania prenatalne lub inne przesłanki medyczne wskazują na duże prawdopodobieństwo ciężkiego i nieodwracalnego upośledzenia płodu albo nieuleczalnej choroby zagrażającej jego życiu, kiedy zachodzi uzasadnione podejrzenie, że ciąża powstała w wyniku czynu zabronionego. Wskazany katalog ma charakter zamknięty. O wystąpieniu okoliczności, o których mowa w art. 4a ust. 1 pkt 1 i 2 ustawy, stwierdza inny lekarz niż dokonujący przerwania ciąży, chyba że ciąża zagraża bezpośrednio życiu kobiety. Kiedy zachodzi okoliczność uzasadnionego podejrzenia, że ciąża powstała w wyniku czynu zabronionego, stwierdzenia tego stanu musi dokonać prokurator.

Ustawa określa, że w przypadku przerwania ciąży w przypadkach określonych $\mathrm{w}$ art. 4a ust. 1 pkt 2 u.p.r. przerwanie ciąży jest dopuszczalne do chwili osiągnięcia przez płód zdolności do samodzielnego życia poza organizmem kobiety ciężarnej. Przerywanie ciąży w przypadku opisanym w ust. 1 pkt 2 u.p.r. ustawy jest określane jako aborcja eugeniczna. Kolejny punkt przedmiotowego artykułu zezwala na dokonanie aborcji, jeżeli od początku ciąży nie upłynęło więcej niż 12 tygodni. W przypadkach, o których mowa w ust. 1 pkt 1 i 2, przerwania ciąży dokonuje lekarz w szpitalu. Na przeprowadzenie zabiegu przerwania ciąży musi wyrazić pisemną zgodę kobieta lub jej przedstawiciel ustawowy (w przypadku małoletniej lub kobiety

13 Dz.U. Nr 17, poz. 78 ze zm. - dalej cytowana jako u.p.r.

14 Trzy przesłanki do śmierci. Wywiad z Prof. A. Zollem w IMAGO - «Czasopismo Fundacji Pro Humana Vita» 4/2011. 
ubezwłasnowolnionej całkowicie). W przypadku małoletniej powyżej 13 roku życia wymagana jest również pisemna zgoda tej osoby. Natomiast w przypadku małoletniej poniżej 13 roku życia wymagana jest zgoda sądu opiekuńczego, a małoletnia ma prawo do wyrażenia własnej opinii. W przypadku kobiety ubezwłasnowolnionej całkowicie wymagana jest także pisemna zgoda tej osoby, chyba że na wyrażenie zgody nie pozwala stan jej zdrowia psychicznego. W razie braku zgody przedstawiciela ustawowego do przerwania ciąży wymagana jest zgoda sądu opiekuńczego. Tajemnica obowiązuje osoby wykonujące czynności będące w związku z przeprowadzaniem zabiegu aborcji. $\mathrm{W}$ razie zawinionego ujawnienia wiadomości objętych tajemnicą sąd może przyznać osobie poszkodowanej odpowiednią sumę tytułem zadośćuczynienia pieniężnego za doznaną krzywdę.

Zgodnie z art. 152 k.k. udzielanie kobiecie ciężarnej pomocy w przerwaniu ciąży z naruszeniem przepisów ustawy lub nakłanianie jej do tego jest czynem zabronionym. Zgodnie z art. $153 \mathrm{kk}$ : „Kto stosując przemoc wobec kobiety ciężarnej lub w inny sposób bez jej zgody przerywa ciążę albo przemocą, groźbą bezprawną lub podstępem doprowadza kobietę ciężarną do przerwania ciąży, podlega karze pozbawienia wolności od 6 miesięcy do lat 8”. Zgodnie z wyrokiem Sądu Apelacyjnego w Katowicach z dnia 30 września 2008 r. ${ }^{15}$, ,czynność sprawcza określona w przepisie art. $152 \S 2 \mathrm{kk}$, odpowiada pomocnictwu w rozumieniu art. $18 \S 3$ k.k." Sąd Apelacyjny w przedmiotowym wyroku rozstrzygnął, że pomoc w postaci kontaktu telefonicznego czy udzielania porad i informacji mieści się $\mathrm{w}$ znamionach przypisanego przestępstwa $\mathrm{z}$ art. $152 \S 2 \mathrm{kk}$.

\section{STAN FAKTYCZNY SPRAWY}

Skarżącymi w przedmiotowej sprawie były obywatelki Polski P. i S., matka i córka. 9 kwietnia 2008 r. P. zgłosiła się do publicznej przychodni uniwersyteckiej w Lublinie, twierdząc, że dzień wcześniej została zgwałcona. 20 maja 2008 r. matka P. konsultowała się z le-

15 II AKa 231/2008, «Krakowskie Zeszyty Sądowe» 10/2009, poz. 64. 
karzami w celu uzyskania pozwolenia na przeprowadzenie aborcji u córki. Tego samego dnia prokurator wydał zaświadczenie, w którym stwierdził, że ciąża P. jest wynikiem obcowania płciowego z małoletnim poniżej 15 roku życia. Skarżące udały się sześć dni później do szpitala Jana Bożego w Lublinie. Podczas wizyty w szpitalu z P. rozmawiał ksiądz katolicki pełniący funkcję diecezjalnego duszpasterza służby zdrowia. W rozmowie z księdzem P. przyznała, że nie może podejmować samodzielnie decyzji i jest zależna od rodziców. Podpisała również oświadczenie, że chce kontynuować ciążę. Ordynator oddziału szpitala odmówiła w związku z tym przeprowadzenia aborcji. W zaistniałej sytuacji S. skontaktowała się z polskim oddziałem International Planned Parenthood (Federacją na rzecz Kobiet i Planowania Rodziny). Organizacja ta nagłośniła całą sprawę w mediach. Sprawa P. stała się elementem bieżącego dyskursu publicznego. 3 czerwca 2008 r. skarżące udały się do Warszawy celem przeprowadzenia aborcji. $\mathrm{Na}$ miejscu zostały poinformowane, że zgodnie z oświadczeniem przesłanym z lubelskiego szpitala P. nie zgadza się na dokonanie aborcji i skarżące opuściły szpital. W związku ze stwierdzeniem nacisków ze strony S. na P., by ta poddała się aborcji, wszczęto postępowanie o ograniczenie praw rodzicielskich zarówno S., jak i ojca P. (niepozostającego w związku małżeńskim z S.), a ją samą przewieziono do jednego z lubelskich ośrodków opiekuńczych. Następnie, po interwencji minister zdrowia, P. uzyskała skierowanie na przeprowadzenie aborcji w szpitalu w Gdańsku, gdzie udała się wraz z matką i została poddana aborcji.

18 listopada 2008 r. P. i S. wniosły przeciwko Polsce do Europejskiego Trybunału Praw Człowieka skargę, podnosząc zarzut naruszenia art. 8 (prawo do poszanowania życia prywatnego i rodzinnego), 3 (zakaz tortur) oraz 5 (prawo do wolności i bezpieczeństwa osobistego) Europejskiej Konwencji Praw Człowieka. 29 listopada 2008 r. skarga została zakomunikowana rządowi polskiemu i - w ocenie Trybunału - jako spełniająca wymogi formalne i materialne została przyjęta do dalszego procedowania.

Rzeczpospolita Polska kwestionowała naruszenie przywołanych supra przepisów Konwencji. Uzasadniając swoje stanowisko, przedsta- 
wiciel rządu polskiego wskazywał m.in. na dobrowolność kontaktów P. z księdzem oraz personelem szpitala Jana Bożego w Lublinie oraz na dobrowolność ujawniania informacji osobom trzecim, w szczególności via sms i komunikatory internetowe (§ 121). Wskazane okoliczności stanowiły dowód dopuszczony do rozpoznania w trakcie postępowania przed sądem rodzinnym. Twierdzenia te zostały ponadto oparte na treści wywiadu środowiskowego oraz na informacjach ze szkoły, z których wynikało, że P. nie była zdecydowana na poddanie się aborcji. Strona polska wskazała także na wynik postępowań krajowych dotyczących zarzutów formułowanych przez skarżące. W postępowaniu krajowym nie było prowadzone postępowanie karne w zakresie przestępstwa zgwałcenia, a jedynie dwa postępowania prowadzone w stosunku do skarżącej i ojca dziecka w przedmiocie obcowania z małoletnim poniżej 15 roku życia (oboje nie ukończyli 15 r. życia - por. $\S 7$ (... by a boy of her own age). Wszystkie te postępowania zostały umorzone. Trybunał został poinformowany o tym fakcie, jednakże nie ustosunkował się do przedstawionych mu wniosków dowodowych. Ponadto, rząd Polski podnosił fakt braku jurysdykcji ETPCz, wynikający z niewyczerpania wszystkich środków odwoławczych przewidzianych prawem wewnętrznym, w szczególności wskazywał na okoliczności niewniesienia powództwa cywilnego z tytułu naruszenia dóbr osobistych P. oraz S. (§ 85). Dwie z organizacji dopuszczonych do udziału w postępowaniu w charakterze strony trzeciej podzielały stanowisko polskiej strony.

\section{Sentencja wyroku oraz Zdanie odręBne}

30 października 2012r. IV Izba ETPCz wydała wyrok w przedmiotowej sprawie ${ }^{16}$. Po pierwsze, Trybunał stwierdził naruszenie art. 8 Konwencji, uznając, że Polska nie zapewniła skarżącej prawa do poszanowania jej życia prywatnego w szczególności przez to, że nie zagwarantowała P. dostępu do aborcji i doszło do ujawnienia danych osobowych podmiotu. W ocenie Trybunału problematyka rozwiązań

16 Wyrok jest prawomocny w związku z powstrzymaniem się przez rząd polski od złożenia wniosku o rozpoznanie sprawy przez Wielką Izbę. 
krajowych dotyczących dopuszczalności zabiegu przerwania ciąży w kontekście poszanowania integralności cielesnej matki mieści się w zakresie art. 8 Konwencji, a obowiązkiem państwa jest faktyczne zagwarantowanie jednostce dostępu do procedury aborcji. Po drugie, Trybunał uznał, że umieszczenie P. w pogotowiu opiekuńczym stanowiło naruszenie Artykułu 5 ust. 1 Konwencji (prawo do wolności i bezpieczeństwa osobistego). Trybunał podniósł, że w celu odseparowania P. od wywierających na nią presję rodziców zastosować można było mniej drastyczne środki. Po trzecie, Trybunał stwierdził naruszenie art. 3 Konwencji, uznając żądanie ze strony lekarzy podpisania zgody na procedurę aborcyjną przez S. za bezprawną presję. Podobnie zakwalifikowano rozmowy prowadzone przez P. z księdzem. Trybunał przyznał pierwszej skarżącej kwotę 30.000 euro, drugiej zaś kwotę 15.000 euro tytułem zadośćuczynienia oraz zasądził kwotę 16.000 euro tytułem zwrotu poniesionych kosztów i wydatków.

Do wyroku zdanie odrębne zgłosił sędzia De Gaetano (Malta). W swoim stanowisku odniósł się on do wyroku R.R. v. Poland $\mathrm{z}$ dnia 26 maja 2011 (skarga 27617/04), podkreślając, że ani Konwencja jako całość, ani w szczególności art. 8 Konwencji nie konstruuje prawa do aborcji. Interpretację art. 8, jaką przeprowadził ETPCz w przedmiotowym wyroku, uznał za wypaczającą prawdziwe znaczenie życia prywatnego i zaprzeczającą wartościom leżącym u podstaw Konwencji, takim. jak wartość życia, która przysługuje nienarodzonemu dziecku niezależnie od tego, czy nazwiemy je nienarodzonym dzieckiem czy płodem - nie zmienia to bowiem jego istoty. Po drugie, sędzia Gaetano podważył zasadność stwierdzenia naruszenia Art. 8 Konwencji w odniesieniu do praw S. Argumentował, że w świetle $\S 109$ wyroku interes S. był również brany pod uwagę przy podejmowaniu decyzji o przerywaniu lub kontynuowaniu ciąży P. (it cannot be overlooked that the interests and life prospects of the mother of a pregnant minor girl are also involved in the decision whether to carry the pregnancy to term or not). Wskazywał, że wykładnia praw podstawowych nie może być dokonywana w kontekście egoistycznych pobudek czy wygody podmiotu. Po trzecie, sędzia wskazywał na obowiązek władz publicznych do poinformowania P. o charakterze zabiegu aborcji i jego moż- 
liwych konsekwencjach. Naruszenie art. 3 Konwencji w jego rozumieniu nie dotyczy faktu prób przekonania P. do kontynuowania ciąży, ale sposobu dokonywania tych prób (publiczne ujawnienie poufnych informacji i zatrzymanie P. w ośrodku opiekuńczym).

\section{WĄTPLIWOŚCI PRAWNE DOTYCZĄCE WYROKU}

Jedną z zasadniczych kwestii wymagających rozstrzygnięcia jest ustalenie, na jakiej podstawie Trybunał strasburski uznał, że ciąża powódki była wynikiem gwałtu, czyli czynem zagrożonym w prawie polskim karą na mocy art. 197 k.k. Wątpliwości w tej mierze wynikają primo z terminologii, którą posługuje się ETPCz w treści orzeczenia, secundo z materiałów dowodowych przedstawianych przez Rzeczpospolitą Polską w trakcie postępowania. Odnosząc się do pierwszej kwestii, należy podnieść, że Trybunał w sposób niejednoznaczny opisuje charakter czynu, którego wynikiem była ciąża skarżącej. Raz Trybunał pisze, że ciąża była wynikiem gwałtu ( $\$ \S 8$ i 100), kiedy indziej pisze o tym samym czynie jako o ,rzekomym gwałcie” (§ 44). Polska kwestionowała te rozbieżności. Zaświadczenie prokuratury, na które ETPCz powołuje się w wyroku, nie wspomina bowiem o gwałcie ani o doprowadzeniu do obcowania płciowego przemocą, groźbą bezprawną lub podstępem. Jak wynika z treści wyroku (§ 10), prokurator stwierdził, że ciąża powódki była wynikiem obcowania płciowego z małoletnim poniżej 15 lat. W świetle tych okoliczności nie znajduje uzasadnienia posługiwanie się przez Trybunał pojęciem gwałtu. $\mathrm{Z}$ tych tez powodów postępowanie prokuratorskie nie było prowadzone w przedmiocie przestępstwa zgwałcenia, a dwa postępowania dotyczące zarzutu obcowania z małoletnim poniżej 15 roku życia zostały umorzone ze względu na małoletniość obydwojga „sprawców”. Co więcej, materiał dowodowy przedstawiony w sprawie sugeruje, że powódka pozostawała w afektywnym związku z ojcem dziecka. Efektem relacji było nowe życie. Trybunał został poinformowany o tych okolicznościach, pozostawił je jednak bez rozpoznania i nie udzielił Rzeczypospolitej Polskiej odpowiedzi w sprawie przedstawionych wniosków dowodowych. 
W ścisłym związku z nader kontrowersyjną kwalifikacją stanu faktycznego, jakiej dokonał ETPCz, pozostaje udział w charakterze interwenienta ubocznego Helsińskiej Fundacji Praw Człowieka. Przedmiotem uwag interwenienta powinien być ogólny krajowy kontekst prawny lub faktyczny, na tle którego powstały okoliczności sprawy $^{17}$. HFPCz zaprezentowała w swojej interwencji problematyczną tezę, w myśl której ofiarom gwałtu nie zapewnia się w Polsce dostępu do aborcji. Bazuje ona wyłącznie na fakcie niewielkiej ilości aborcji w porównaniu do ilości odnotowywanych gwałtów, czego nie sposób uznać nie tylko za dowód, ale nawet za uprawdopodobnienie forsowanej tezy. Biorąc pod uwagę zarówno materiał dowodowy przedstawiony przez stronę polską (brak postępowania karnego z tytułu przestępstwa zgwałcenia oraz treść zaświadczenia prokuratora), jak i rozbieżności w samym wyroku, wyraźnie widać, że ani kontekst faktyczny, ani prawny nie uzasadniał podjęcia w interwencji problematyki gwałtu. Fakt, że bezpodstawne zakwalifikowanie sprawy jako dotyczącej gwałtu stało się dodatkowo głównym motywem wyroku (wyeksponowanym również w materiałach prasowych Trybunału), potęguje te wątpliwości.

Poważne wątpliwości budzi również twierdzenie Europejskiego Trybunału Praw Człowieka, zgodnie z którym prawo polskie przyznaje ,prawo do aborcji” ( 153$)$, którego podmiotem miałaby być matka dziecka eliminowanego $\mathrm{w}$ drodze tej procedury. Tymczasem ani przepisy prawa krajowego, ani Europejska Konwencja Praw Człowieka takiego prawa nie przewidują. Na gruncie prawa polskiego twierdzenie takie jest podwójnie bezzasadne.

Po pierwsze, polski ustawodawca nie ustanowił w żadnym akcie normatywnym prawa podmiotowego do aborcji, a jedynie dopuścił w art. 4a u.p.r trzy kontratypy zasady kryminalizującej aborcję, mówiąc o możliwości przerwania ciąży. Adresatem przepisu art. 4a u.p.r. jest lekarz przeprowadzający aborcję, nie zaś matka dziecka. W konsekwencji przepis ten zmienia jedynie sytuację prawną lekarza. W praktyce

17 L. Garlicki, [w:] Konwencja o Ochronie Praw Człowieka i Podstawowych Wolności, II, red. L. GARLICKI, Warszawa 2011, s. 196-197. 
oznacza to, że, co do zasady, lekarz podlega odpowiedzialności karnej za przeprowadzenie aborcji (zgodnie z art. $152 \S 1$ k.k.: „kto za zgodą kobiety przerywa jej ciążę z naruszeniem przepisów ustawy, podlega karze pozbawienia wolności do lat 3"), chyba że zajdą przesłanki z art. 4a u.p.r. Natomiast matka nigdy nie podlega odpowiedzialności karnej z tytułu poddania się aborcji. Tym samym z art. 4a wynikają bezpośrednie skutki wyłącznie dla lekarza. Jedynie pośrednio, przez stworzenie sytuacji uchylającej karalność lekarza, kobieta zyskuje faktyczne możliwości działania. Są to jednak jedynie refleksy prawne (refleksyjne działania prawa przedmiotowego - reflexive Wirkungen), nie zaś prawa podmiotowe ${ }^{18}$.

Po drugie, powyższa argumentacja znajduje uzasadnienie na poziomie konstytucyjnym. Zdaniem Trybunału Konstytucyjnego, wyrażonym w wyroku z dnia 28 maja 1997 r. ${ }^{19}$, art. 4a u.p.r. ma charakter legalizujący określone zachowania zmierzające do przerwania ciąży, ergo zawiera upoważnienie do podjęcie określonych działań co do zasady zabronionych i podlegających karze. Wynika to z faktu, że wartością nadrzędną, podlegającą ochronie prawnej, jest prawo do życia. Jest ono wyprowadzane z polskich przepisów konstytucyjnych i przysługuje - jako prawo podmiotowe - każdemu człowiekowi ${ }^{20}$. Pozbawienie życia unicestwia człowieka jako podmiot praw i obowiązków. Jeżeli istotną treścią zasady państwa prawa jest ochrona praw człowieka, to wstępnym warunkiem jej urzeczywistnienia jest ochrona samego człowieka - podmiotu praw, wyrażająca się ochroną ludzkiego prawa do życia. W demokratycznym państwie prawa musi zatem pozostawać ono pod ochroną konstytucyjną w każdym stadium jego rozwoju ${ }^{21}$. Stanowisko to potwierdził i rozwiną Trybunał Kon-

18 Por. koncepcję działań refleksywnych prawa przedmiotowego w ujęciu R. von Iheringa: R. vON IHERING, Geist des römischen Rechts auf den verschiedenen Stufen seiner Entwicklung, Darmstadt 1954, III.1, s. 351 i n.

19 K 26/96, «OTK» 2/1997.

20 L. GARLICKI, Zdanie odrębne do wyroku Trybunatu Konstytucyjnego z dnia 28 maja 1997 r., K 26/96, «OTK ZU» 2/1997, poz. 19.

21 Wyrok TK z dnia 28 maja 1997 r., K 26/96, «OTK» 2/1997. 
stytucyjny w wyroku z dnia 27 stycznia 2004 r. $^{22}$, uznając, że art. 38 Konstytucji, zapewniający każdemu człowiekowi prawną ochronę życia, ma szczególne znaczenie i rodzi przez to określone konsekwencje wobec ustawodawcy zwykłego. Nie można mówić o ochronie godności człowieka, jeśliby ustawodawca tworzył prawo podmiotowe do pozbawienia życia niewinnego człowieka (niemożność przypisania winy za czyn zabroniony człowiekowi w prenatalnej fazie rozwoju jest zbyt oczywista, by wymagała uzasadnienia). Wynika $\mathrm{z}$ tego, że korelatem praw podmiotowych są obowiązki, których adresatem jest ustawodawca. Sprowadzają się z jednej strony do nakazu stanowienia norm prawnych umożliwiających realizację prawa podmiotowego, z drugiej - do zakazu wprowadzania rozwiązań normatywnych uniemożliwiających korzystanie $\mathrm{z}$ gwarantowanych prawem podmiotowym uprawnień ${ }^{23}$. W tym kontekście depenalizacja aborcji w pewnych sytuacjach nie kreuje bynajmniej prawa podmiotowego, lecz stanowi jedynie wyjątek od ogólnej zasady, nosząc znamiona kontratypu ${ }^{24}$. Co więcej, konstytucyjność dokonanego przez ustawodawcę zwykłego wyważania między wartościami bynajmniej nie jest bezsporna. Do tej pory wszystkie przesłanki aborcyjne, których konstytucyjność była badana, zostały uznane za niekonstytucyjne i wiele wskazuje na to, że podobnie stałoby się w przypadku kontroli konstytucyjności pozostałych przesłanek z art. 4a ustawy o planowaniu rodziny, których konstytucyjności jeszcze nie badano i które wciąż jeszcze obowiązują.

W tym kontekście, omawiane stanowisko ETPCz uwiarygodnia formułowane w doktrynie tezy o podejmowaniu przez Trybunał działań obliczonych na skłonienie Polski oraz Irlandii przez Radę Europy

22 K 14/03, «OTK-A» 1/2004, poz.1.

23 M. BŁachut, Pojęcie prawa podmiotowego w orzecznictwie Trybunału Konstytucyjnego. [w:] Problemy bezpieczeństwa prawnego z perspektywy teorii i filozofi prawa, red. J. JABŁoŃSKA-Bonc, J. Guść, «Gdańskie Studia Prawnicze» 9/2002, s. 183.

24 M. WILD, Roszczenia z tytulu wrongfulbirth w prawie polskim (Uwagi na tle wyroku Sądu Najwyższego z dnia 21 listopada 2003 r., V CK 16/03), «Przegląd Sądowy» 1/2005, s. 51 i 53. 
do legalizacji aborcji ${ }^{25}$. Takie działanie jednak nie znajdowałoby żadnych podstaw w prawie międzynarodowym. Jeśli teza ta potwierdziłaby się, uznać należałoby ją za działanie wysoce niestosowne i stojące w sprzeczności chociażby z decyzją Europejskiej Komisji Praw Człowieka z dnia 19 maja 1992 r. w sprawie H. przeciwko Norwegii ${ }^{26}$, w której przyznano, że z uwagi na delikatność materii aborcyjnej, należy zapewnić $\mathrm{w}$ tej mierze państwom pełną swobodę działania.

W wyroku brak jest danych, które pozwalałyby uznać za uzasadnione stanowisko Trybunału ( $(102)$, zgodnie z którym lekarze naciskali i forsowali własne poglądy i idee, nie zaś kierowali się wiedzą medyczną oraz obowiązkiem prawnym wynikającym z przepisów ustawowych, informując pacjentkę o następstwach zastosowania zabiegu przerwania ciąży i wymagając pisemnej zgody na zabieg. Twierdzenie to nie znajduje oparcia na gruncie stanu faktycznego. Co więcej, $\mathrm{w}$ świetle polskiego prawa rezerwa w stosunku do żądań przeprowadzenia aborcji była nie tylko całkowicie uzasadnione, ale stanowiła wręcz obowiązek lekarzy. Trybunał, dokonując kwalifikacji prawnych, zapomniał o tym, że lekarze dysponowali pisemnym oświadczeniem P. o woli kontynuowania ciąży. W tym kontekście zarzut naruszenia przepisów konwencyjnych przez to, że od S. wymagano podpisania oświadczenia informującego o możliwych konsekwencjach przeprowadzenia aborcji (poważny rozstrój zdrowia ze śmiercią włącznie), ujawnia wewnętrzną sprzeczność w rozumowaniu ETPCz i oczywistą niekonsekwencję w budowaniu uzasadnienia wyroku.

Stosownie do przepisu art. 34 ust. 1 ustawy z dnia 5 grudnia 1996 r. o zawodach lekarza i lekarza dentysty ${ }^{27}$ oraz art. 19 ust. 1 pkt 2 ustawy z dnia 30 sierpnia 1991 r. o zakładach opieki zdrowotnej ${ }^{28} \mathrm{i} \mathrm{w}$ zw. $\mathrm{z}$ art. 4 ust. 4 ustawy z dnia 7 stycznia 1993 r. u.p.r., lekarz może wykonać zabieg stwa-

25 Por. $W$ jaki sposób Rada Europy narzuca aborcję Irlandii i Polsce. Analiza Dyrektora ECLJ dra Gregora Puppincka, http://www.ordoiuris.pl/w-jaki-sposobrada-europy-narzuca-aborcje-irlandii-i-polsce--analiza-dyrektora-eclj-dra-gregorapuppincka,3205,analiza-prawna.html, dostęp z dnia 3 marca $2013 \mathrm{r}$.

26 Skarga nr 17004/90, DR 73/155.

27 Tekst jedn. Dz.U. z 2011 r. Nr 277, poz. 1634 - dalej cytowana jako u.z.l.

28 Tekst jedn. Dz.U. z 2007 r. Nr 14, poz. 89 - dalej cytowana jako u.z.o.z. 
rzający podwyższone ryzyko dla pacjenta po uzyskaniu jego pisemnej zgody. Jednocześnie z treści art. 4 ust. 4 u.p.r. wynika expressis verbis, że przeprowadzenie aborcji jest możliwe po uzyskaniu pisemnej zgody na zabieg, ergo wykładnia systemowa prowadzi do wniosku, że zabieg przerwania ciąży stwarza $\mathrm{w}$ rozumieniu ustawodawcy podwyższone ryzyko dla kobiety. Pogląd ten znajduje potwierdzenie na gruncie doktryny. Zdaniem M. Safjana decyzja na zabieg musi zostać powzięta na podstawie należytego rozpoznania okoliczności faktycznych (tzw. zgoda poinformowana) i wyrażona we właściwej formie ${ }^{29}$. Jak zauważa D. Karkowska, zabieg przerwania ciąży należy do zabiegów, które ze swej istoty zaliczają się do stwarzających podwyższone ryzyko ${ }^{30}$. W praktyce przejawia się ono w szczególności w możliwości przebicia ściany macicy, co może doprowadzić do krwotoku i stanu zapalnego w obrębie jamy otrzewnej, wystąpienia powikłań po podaniu znieczulenia oraz naruszenia ciągłości bariery chroniącej wnętrze macicy (możliwy stan zapalny z jamie macicy). Wskazane komplikacje nie pozostają często bez wpływu na stan zdrowia kobiety w perspektywie długoterminowej. Zaobserwowane i szczegółowo udokumentowane w badaniach medycznych możliwe konsekwencje to w szczególności bezpłodność, poronienia, ciąża pozamaciczna, zwiększone ryzyko zachorowania na raka, liczne konsekwencje o podłożu psychicznym oraz zgon $^{31}$. W związku z tym twierdzenie zawarte w wyroku, jakoby w okolicznościach przedmiotowej sprawy nie istniały podstawy do uznania zabiegu przerwania ciąży za procedurę stwarzającą podwyższone zagrożenie dla zdrowia kobiety, wynika z nieznajomości natury procedury aborcyjnej, która jest niebezpieczna z samej swej istoty. Nie muszą wystąpić żadne szczególne okoliczności, by w wyniku aborcji

29 Por. M. SAfJan, Autonomia jednostki wobec interwencji medycznej, [w:] Prawo $i$ medycyna. Ochrona praw jednostki a dylematy współczesnej medycyny, Warszawa 1998 , s. 62.

30 D. Karkowska, Prawa pacjenta, Warszawa 2009, s. 437.

31 Por. w szczególności E. Ring-CAssidy, I. Gentles, Women's health after abortion: the medical and psychological evidence. Toronto, The deVeber Institute, 2003; D.C. REARDON ET AL., Deaths associated with pregnancy outcome: a record linkage study of low income women, «Southern Medical Journal» (8)95/2002, s. 834-841. 
pojawiło się poważne ryzyko dla zdrowia. Twierdzenie ETPCz jest tym bardziej nieuzasadnione, że Trybunał w swoim wcześniejszym orzecznictwie konsekwentnie utrzymywał, że brak zgody na ryzykowną procedurę medyczną, wyrażonej na podstawie przystępnej informacji lekarskiej, skutkuje naruszeniem art. 3 i 8 Konwencji (V.C. przeciwko Stowacji (nr 18968/07) § 114, N.B. przeciwko Słowacji (nr 29518/10). Rozstrzygnięcie w sprawie $P$. i S. przeciwko Polska wprowadza zatem istotną niespójność w linii orzeczniczej ETPCz i tym samym stanowi poważne zagadnienie dotyczące interpretacji lub stosowania Konwencji w aspekcie materialnym. W myśl art. $43 \S 2$ EKPCz okoliczność ta uzasadnia wniosek o przekazanie sprawy do Wielkiej Izby. Jest to tym bardziej uzasadnione z uwagi na fakt, że wyrok izby dotyczyłby kwestii, która stała się przedmiotem rozbieżnych rozstrzygnięć orzeczniczych prowadząc do trudności w ustaleniu stanowiska ETPCz ${ }^{32}$.

W kontekście drugiego zarzutu Trybunału należy podnieść, że nieprzekazanie przez lekarzy informacji o możliwych powikłaniach proaborcyjnych jest sprzeczne $\mathrm{z}$ obowiązującymi rozwiązaniami normatywnymi. Stosownie do treści art. 31 ust. 1 ustawy z dnia 5 grudnia 1996 r. u.z.l. lekarz ma obowiązek udzielić pacjentowi lub jego przedstawicielowi ustawowemu przystępnej informacji o jego stanie zdrowia, rozpoznaniu, proponowanych oraz możliwych metodach diagnostycznych, leczniczych, dających się przewidzieć następstwach ich zastosowania albo zaniechania, wynikach leczenia oraz rokowaniu. Ponadto, obowiązek udzielenia informacji wynika z art. 9-12 ustawy z dnia 6 listopada 2008 r. o prawach pacjenta i Rzecznika Praw Pacjen$\mathrm{ta}^{33}$. Powiadomienie pacjenta o metodach, perspektywach i skutkach leczenia, rozumiane jako pouczenie, informacja, jest obowiązkiem lekarza, od którego nie ma prawa uchylać się i za którego niedopełnienie odpowiada. Informacja warunkująca skuteczną zgodę na działanie medyczne musi nie tylko spełniać określone wymagania co do treści, lecz również co do formy. Powinna zostać przekazana w sposób przystępny

32 Por. L. Garlicki, [w:] Konwencja o Ochronie Praw Człowieka i Podstawowych Wolności..., II, s. 335.

33 Tekst jedn. Dz.U. z 2012 r. Nr 00, poz. 159. 
i zrozumiały dla pacjenta, umożliwiając mu - po jej przeanalizowaniu - dokonanie świadomych wyborów dotyczących leczenia ${ }^{34}$. Jednocześnie pacjent ma prawo uzyskać informacje na temat możliwych sposobów leczenia i skutków, jakie się z nimi wiążą. Jest to niezbędne dla wyrażenia zgody na określony sposób leczenia. Wynika to $\mathrm{z}$ faktu, że zgoda pacjenta wyrażona bez rozeznania jest niepełna i może być dotknięta wadą oświadczenia woli, mianowicie błędem (art. $84 \S 2$ k.c.) lub brakiem świadomości lub swobody (art. 82 k.c.) $)^{35}$.

Pogląd ten znajduje uzasadnienie na gruncie orzecznictwa Sądu Najwyższego. Jak zauważył Sąd Najwyższy w wyroku z dnia 28 września 1999 r. ${ }^{36}$, wyrażenie zgody na zabieg operacyjny przez chorego (jego przedstawiciela ustawowego lub faktycznego opiekuna) powinno być poprzedzone udzieleniem przez lekarza informacji co do dających się przewidzieć możliwych następstw zabiegu, a brak takiej informacji sprawia, że zgoda jest bezskuteczna, wobec czego wykonanie zabiegu następuje tak, jak gdyby nie została ona w ogóle wyrażona. Pogląd ten podtrzymał i rozwinął Sąd Najwyższy w wyroku z dnia 17 grudnia 2004 r. ${ }^{37}$, twierdząc, że o wyrażeniu przez pacjenta zgody na wykonanie zabiegu operacyjnego można mówić tylko wówczas, gdy została ona poprzedzona udzieleniem pacjentowi przystępnej informacji. Oznacza to, że brak udzielenia pacjentowi takiej informacji przesądza zarazem o braku wyrażenia przez pacjenta uświadomionej zgody na zabieg. Wykonanie w takiej sytuacji zabiegu operacyjnego oznacza wykonanie go w warunkach bezprawności. Podobnie uznał Sąd Najwyższy w wyroku z dnia 16 maja 2012 r. ${ }^{38}$ W ocenie Sądu sama aprobata pacjenta dla dokonania zabiegu, uzyskana w sytuacji braku uprzedniego udzielenia mu przystępnej informacji, nie może być traktowana jako zgoda. Zgoda pacjenta musi być zgodą objaśnioną, poin-

34 A. DudzIŃSKA, Wymagana informacja udzielana pacjentowi, «PiP» 63.8/2008, s. 90

35 Ustawa o zawodach lekarza i lekarza dentysty. Komentarz, red. L. OGIEGŁo Warszawa 2010, s. 291.

36 II CKB 511/96, «LexPolonica» 1511162.

37 III CK 303/2004, «OSP» 2/2005, s. 67.

38 III CSK 227/11, «Biuletyn SN» 2/2012. 
formowaną, a więc świadomie akceptującą przez pacjenta zrozumiałe przezeń ryzyko dokonania zabiegu i przejęcie na siebie tego ryzyka.

Stanowisko Sądu Najwyższego znajduje odbicie w orzecznictwie sądów niższych instancji. Sąd Apelacyjny w Gdańsku w wyroku z dnia 26 lutego 2010 r. ${ }^{39}$ uznał, że zaniechanie przez lekarza poinformowania pacjenta o wszystkich konsekwencjach wynikających z zastosowania metody leczniczej narusza dyspozycję art. 31 u.z.1., jak również pozbawia pacjenta możliwości wyboru i współdecydowania o sposobie leczenia. Podobnie uznał Sąd Apelacyjny w Warszawie w wyroku z dnia 31 marca 2006 r. $^{40}$, uznając, że zabieg operacyjny $\mathrm{z}$ ich zastosowaniem powinien być przeprowadzony po przekazaniu pacjentowi w tym zakresie szczegółowych informacji i po uzyskaniu kwalifikowanej zgody w formie pisemnej (art. 34 cyt. ustawy). Powinien on w związku $\mathrm{z}$ tym znać przedmiot zgody, metodę leczenia, ryzyko i następstwa - zwłaszcza nieodwracalne. W doktrynie prawniczej i orzecznictwie sądowym wskazuje się, że znaczenie zgody polega na tym, iż nadaje ona działaniu lekarza cechę prawnej interwencji, a pacjent poznał i akceptuje ryzyko zabiegu i przejmuje je na siebie. Zabieg medyczny dokonany bez zgody jest czynnością bezprawną nawet wówczas, gdy wykonany jest zgodnie z zasadami wiedzy. Podobnie orzekł Sąd Apelacyjny w Poznaniu w wyroku z dnia 29 września 2005 r. $^{41}$, twierdząc, że lekarz odpowiada nie tylko za winę w samym procesie leczenia, lecz także za każdą winę niedotyczącą techniki medycznej, a więc i za niedoinformowanie pacjenta o ryzyku i skutkach zabiegu. Samo zaś uzyskanie formalnej zgody pacjenta bez poinformowania go o ryzyku i skutkach zabiegu powoduje, że jest to zgoda „nieobjaśniona” i jako taka jest wadliwa, wskutek czego lekarz działa bez zgody i naraża się na odpowiedzialność cywilną za szkodę wyrządzoną pacjentowi, nawet gdy postępuje zgodnie z zasadami sztuki lekarskiej.

\footnotetext{
39 I ACa 51/10, «Przegląd OSA w Gdańsku» 3/2010, poz. 2.

40 I ACa973/2005, «OSA» 1/2008, poz. 2, s. 39.

41 I ACa 236/05.
} 
Zagadnieniem wymagającym rozstrzygnięcia jest ustalenie, na jakim materiale dowodowym ETPCz oparł swoje stanowisko, w myśl którego Polska naruszyła art. 3 Konwencji, nie chroniąc powódki przed kontaktami z osobami odradzającymi jej aborcję (§ 164), podobnie jak i rzekomo P. „miała być, bez pytania o chęć kontaktów z duchownym, zmuszana do rozmów z księdzem" ( $\$ 81$ i 163). Wskazane twierdzenia budzą szereg wątpliwości w kontekście przedstawionego przez Rzeczpospolitą Polską materiału dowodowego opartego na treści wywiadu środowiskowego, informacji ze szkoły, do której uczęszczała skarżąca, które wskazywały na wątpliwości małoletniej co do przeprowadzenia aborcji.

Po pierwsze, zarzut naruszenia przez Polskę art. 3 Konwencji, według którego jakoby państwo polskie nie chroniło powódki przed kontaktami z osobami odradzającymi jej aborcję, wobec braku jednoznacznych materiałów dowodowych na tę okoliczność, jest nieuzasadniony. Wynika to z faktu, że - jak zauważa L. Garlicki - każdy przypadek uznany za nieludzkie lub poniżające traktowanie wymaga przekonywującego udowodnienia. Stanowisko to znajduje również uzasadnienie w orzecznictwie ETPCz, na gruncie którego można uznać, że nieludzkie lub poniżające traktowanie jako formy maltretowania powinny być wykazane ,ponad rozsądną wątpliwość”42.

Po drugie, stosownie do art. 10 ustawy o prawach pacjenta, pacjent, niezależnie od obywatelstwa, wyznania czy wieku, ma prawo do opieki duszpasterskiej. Wskazane uprawnienie jest realizacją gwarancji wynikającej z art. 53 Konstytucji RP, zapewniającej każdemu człowiekowi przebywającemu na terytorium RP prawo do wolności sumienia i religii (prawo wolnościowe). Treść prawa do opieki duszpasterskiej obejmuje w szczególności uprawnienie do bycia poinformowanym, gdzie w ciągu dnia przebywają kapelani, w jaki sposób można się z nimi skontaktować oraz uprawnienie do bezpośredniego kontaktu z opiekunem duchowym ${ }^{43}$. W kontekście stanowiska ETPCz wyra-

42 L. Garlicki, [w:] Konwencja o Ochronie Praw Człowieka i Podstawowych Wolności ..., I, s. 113.

43 D. KarkowsKa, op. cit., s. 485-486. 
żonego bez oparcia się na odpowiednich materiałach dowodowych oraz wskazanych supra rozwiązań normatywnych nie można uznać za bezsporne, że powódka była bez pytania o chęć kontaktów z duchownym zmuszana do rozmów z księdzem. Tym bardziej, że zagadnieniem wymagającym rozstrzygnięcia jest ustalenie, czy zabezpieczono oraz przedstawiono w postępowaniu przed ETPCz materiał dowodowy znajdujący się w posiadaniu księdza, z którym kontaktowała się powódka podczas swego pobytu w szpitalu, a w świetle którego można byłoby lepiej określić charakter kontaktów między powódką i duchownym, podobnie jak to, kto był ich inicjatorem oraz to, pod czyją presją znajdowała się powódka w trakcie pierwszych 12 tygodni jej ciąży. Diecezjalny duszpasterz służby zdrowia, z którym kontaktowała się powódka, dysponuje pisemnym zaproszeniem dziewczyny. Znajduje się w posiadaniu wiadomości tekstowych, z których jasno wynika, że powódka czuła się zagubiona, zmagała się z trudną sytuacją, nie była gotowa na przeprowadzenie aborcji, a nawet wyrażała zainteresowanie płcią dziecka. Jednocześnie pozytywnie wypowiadała się o zapewnionej jej opiece medycznej. W kontekście powyższych twierdzeń należy uznać, że materiał dowodowy, o którym mowa supra, wskazuje, że to powódka zabiegała o rozmowy z księdzem. Tym samym ingerencja funkcjonariuszy publicznych i utrudnianie kontaktów powódki z księdzem i z lekarzami stanowiłyby pogwałcenie Europejskiej Konwencji Praw Człowieka, zwłaszcza jej art. 8, dotyczącego prawa do prywatności i 9, gwarantującego wolność myśli, sumienia i wyznania, traktowanych jako jeden z fundamentów społeczeństwa demokratycznego. Jest to szczególnie widoczne w kontekście treści art. 9 EKPCz. Przedmiotowe unormowanie gwarantuje m.in. wolność uzewnętrzniania „wyznania lub przekonań”, co wiąże się z interakcją społeczną przez komunikowanie się z innymi osobami ${ }^{44}$.

W kontekście powyższych ustaleń nie znajduje uzasadnienia decyzja polskiej strony postępowania o niewniesieniu sprawy do Wielkiej Izby Trybunału. Nie budzi wątpliwości twierdzenie, że te same dzia-

44 L. Garlicki [w:] Konwencja o Ochronie Praw Człowieka i Podstawowych Wolności..., I, s. 552. 
łania, które w sprawach V.C. przeciwko Słowacji, oraz N.B. przeciwko Słowacji Europejski Trybunał Praw Człowieka uznał za konieczne w świetle art. 3 i 8 EKPCz, w sprawie $P$. i S. przeciwko Polsce tenże Trybunał uznał za naruszające te same artykuły Konwencji. Okoliczność ta wydaje się stanowić poważne zagadnienie dotyczące interpretacji lub stosowania Konwencji w aspekcie materialnym, które w myśl art. 43 § 2 EKPCz uzasadnia wniosek o przekazanie sprawy do Wielkiej Izby. Potraktowanie wymagania od S. poinformowanej zgody na aborcję jako przejaw nieludzkiego traktowania wprowadza zasadniczą niespójność w sposobie rozumienia gwarancji Konwencyjnych. Za przekazaniem sprawy do Wielkiej Izby przemawiał dodatkowo fakt istnienia zdania odrębnego, dotyczącego meritum sprawy ${ }^{45}$. Wydaje się, że obawy wyrażone przez stronę polską w kontekście skierowania sprawy do Wielkiej Izby Trybunału nie są usprawiedliwione.

\section{WNIOSKI}

Należy zgodzić się z twierdzeniem, że gwarancje ochrony praw podstawowych przewidziane przez Konwencję muszą być na tyle elastyczne, by mogły być w sposób możliwie jednolity stosowane w różnorodnych warunkach panujących w poszczególnych państwach przy jednoczesnym poszanowaniu suwerenności państw-stron Konwencji i uznaniu subsydiarnego charakteru przedmiotowej umowy międzynarodowej ${ }^{46}$. Jednakże trybunał strasburski zdaje się nie ograniczać w zakresie orzekania do minimalnego standardu i traktuje Konwencję jak ,żywy instrument”, który wykorzystuje w swobodny sposób w zakresie kształtowania treści norm prawnych ${ }^{47}$. W konsekwencji prowadzi to do ograniczeń marginesu swobodnego uznania, którym cieszą się państwa-strony Konwencji ${ }^{48}$. Jest to szczególnie widoczne w wielu

45 Por. L. Garlicki, [w:] Konwencja o Ochronie Praw Człowieka i Podstawowych Wolności..., II, s. 335.

46 A. STĘPKowsKi, Zasada proporcjonalności w europejskiej kulturze prawnej, Warszawa 2010, s. 213.

47 C. GRewe, op. cit., s. 293.

48 A. STĘPKOWSKI, op. cit., s. 229. 
ostatnich kontrowersyjnych rozstrzygnięciach, które budziły w europejskiej kulturze prawnej szereg wątpliwości i wywoływały ożywioną dyskusję wśród przedstawicieli jurysprudencji. Przykładem może być wyrok ETPCz z dnia 1 marca 2010 r. w sprawie Lautsi przeciwko Włochom $^{49}$, który wywołał tak wielki sprzeciw wśród państw-stron Konwencji, że na rozprawie przed Wielką Izbą Trybunału prawie połowa członków konwencyjnego systemu ochrony praw podstawowych manifestowała swoją solidarność z Włochami.

Szereg uzasadnionych wątpliwości budzi także kontrowersyjny wyrok Europejskiego Trybunału Praw Człowieka w sprawie P. i S. przeciwko Polsce. W wyroku przedstawiono całą sprawę jako powstałą w wyniku gwałtu, nie posiadając po temu realnych podstaw w materiale dowodowym. Znajduje to potwierdzenie w braku spójności pomiędzy poszczególnymi sformułowaniami wyroku, w którym raz mówi się o ciąży powstałej w wyniku gwałtu ( $\$ \S 8$ i 100), a innym razem o „rzekomym gwałcie” (§ 44). Co więcej, sposób zaprezentowania stanu faktycznego, na którym Trybunał oparł swój wyrok w omawianej sprawie, kontrastuje z treścią dokumentów będących przedmiotem wniosków dowodowych strony polskiej. W zaświadczeniu prokuratury, które było podstawą poddania P. procedurze aborcyjnej, ciąża skarżącej była wynikiem obcowania płciowego z małoletnim poniżej 15 lat. W postępowaniu krajowym nie było prowadzone postępowanie karne w przedmiocie przestępstwa zgwałcenia, a dwa postępowania dotyczące zarzutu obcowania z małoletnim poniżej 15 roku życia zostały umorzone (oboje ,sprawców” nie podlegało odpowiedzialności ze względu na małoletniość). Jednocześnie materiał dowodowy przedstawiony w sprawie wskazuje, że ciąża P. była konsekwencją pozostawania skarżącej w afektywnym związku z ojcem dziecka. Trybunał strasburski pozostawił przedmiotowe wnioski dowodowe bez rozpoznania i bez udzielenia Rzeczypospolitej Polskiej odpowiedzi w tej sprawie. Podobnie, ETPCz nie uwzględnił dowodu W postaci pisemnego zaproszenia księdza do rozmów ze skarżącą. Trybunał autorytarnie ocenił fakt spotkań P. z księdzem w kategorii

49 Skarga nr 30814/06. 
niechcianych kontaktów skarżącej z osobą duchowną, zarzucając naruszenie art. 3 Konwencji w postaci nieludzkiego lub poniżającego traktowania. Biorąc pod uwagę, że każdy przypadek nieludzkiego lub poniżającego traktowania wymaga przekonywującego udowodnienia „ponad rozsądną wątpliwość" dowodowy, należy uznać, że ustalenia Trybunału są co najmniej wątpliwe z prawnego punktu widzenia.

Po trzecie, biorąc pod uwagę powyższe, nie można zgodzić się z twierdzeniem, że udzielenie informacji o niebezpieczeństwie związanym z procedurą medyczną oraz przewidziane prawem wymaganie zgody na jej przeprowadzenie można uznać za przejaw nieludzkiego traktowania. Przeprowadzona analiza prowadzi do jednoznacznych wniosków, że lekarze, informując skarżące o specyfice procedury medycznej i wymagając pisemnej zgody na przeprowadzenie zabiegu, realizowali nałożony na nich ustawowy obowiązek, ergo ich działanie było zgodne z prawem oraz standardami obowiązującymi na gruncie EKPCz. Trybunał w sposób nieuzasadniony zakwestionował działania podejmowane na podstawie obowiązującego prawa przez lekarzy, deprecjonując w ten sposób ich wiedzę medyczną i postawę etyczną zaledwie na podstawie subiektywnych odczuć skarżących ${ }^{51}$.

Wszystkie te wątpliwości sprawiają, że trudno jest lekceważyć zarówno daleko idącą tezę Grégora Puppincka o wywieraniu przez Radę Europy presji na państwa penalizujące aborcję celem liberalizacji ich prawa wewnętrznego, jak i polityczną doniosłość sformułowanych przez włoskiego deputowanego Luca Volontè problemów w pytaniu nr 633 skierowanym do Komitetu Ministrów RE.

50 L. Garlicki, [w:] Konwencja o Ochronie Praw Człowieka i Podstawowych Wolności..., I, s. 113.

51 Por. M. GaŁĄzKa, Glosa do wyroku Europejskiego Trybunału Praw Człowieka z dnia 20 marca 2007 r. w sprawie Alicja Tysiąc przeciwko Polsce (nr skargi 5410/03), «Przegląd Sejmowy» 3(80)/2007, s. 220. 
Is the European Convention on Human Rights Treated as A "Living Instrument" Affording Better Protection of Human Life?

\section{Summary}

The Strasbourg Court appears to be using the provisions of the European Convention on Human Rights in a free way to shape the content of legal norms. The purpose of this article is to exemplify this controversial process by the judgement of $30^{\text {th }}$ October 2012 in P. and S. v. Poland, which, as some commentators have already observed, appears to be tending to the construction of a right to abortion alleging Article 8 of the Convention considered completely out of the context of the guarantees for the protection of human life in Article 2. The judgement shows that the Court treated the case as based on grounds resulting from rape, but no evidence was produced to corroborate these grounds. This is confirmed by the lack of consistency between the particular formulations of the judgement. Furthermore, the way in which the facts were presented, on which the Court based its judgement, is not in agreement with the content of the documents produced as evidence by Poland. The Court left a series of points of evidence unexamined, and raised unwarranted reservations on the action the doctors had taken in compliance with Polish law. In effect the European Court of Human Rights treated the same course of action which it had deemed necessary in the proceedings of V.C. v. Slovakia, and N.B. v Slovakia as a violation of Articles 3 and 8 of the ECHR in the case of P. and S. v. Poland. This fact seems to raise a serious issue regarding the interpretation or application of the Convention in the context of the material. 